- Victor W ünsch-Filho

- Paolo Boffetta

- Didier Colin

- José Eduardo Moncau

\section{Familial cancer aggregation and the risk of lung cancer}

\author{
D epartment of E pidemiology, Faculty of Public H ealth, U niversity of São \\ Paulo, São Paulo, Brazil
}

\section{ABSTRACT}

CONTEXT: A round $90 \%$ of lung cancer worldwide is attributable to cigarette smoking, although less than $20 \%$ of cigarette smokers develop lung cancer. 0 ther factors such as diet, chronic lung diseases, occupation and possibly environmental agents also contribute to this cancer. G enetic factors seem to play a role in lung cancer, but the precise characteristics influencing lung cancer susceptibility are not known, since genetic factors are easily obscured by the strong environmental determinants of lung cancer, particularly smoking.

OBJECTIVE: To estimate the effect that cancer occurrence among first-degree relatives has on the risk of lung cancer.

DESIGN: Hospital-based case-control study.

SETTING: The metropolitan region of São Paulo, Brazil.

PARTICIPANTS: 334 incident lung cancer cases and 578 controls matched by hospitals.

MAIN MEASUREMENTS: By means of a structured questionnaire, cases and controls were interviewed about cancer occurrence in first-degree relatives, tobacco smoking, exposure to passive smoking, occupation, migration and socioeconomic status. $\mathrm{N}$ on-conditional logistic regression was used to calculate the risk of familial cancer aggregation, the effect of cancer in first-degree relatives and smoking in conjunction, and for controlling confounders.

RESULTS: The adjusted odds ratio (O R) revealed a slight, but not statistically significant, excess risk of lung cancer for subjects with a history of lung cancer in relatives (OR 1.21; $95 \%$ confidence interval [CI] $0.50-2.92$ ). The same was found among those with a history of other tobacco-related cancers in relatives (OR $1.36 ; 95 \% \mathrm{Cl} 0.87-2.14)$. A step gradient effect was observed regarding lung cancer risk, in accordance with increases in the number of pack-years of cigarette consumption. An interaction between familial cancer aggregation and tobacco smoking was detected.

CONCLUSIONS: A mildly elevated risk of lung cancer among persons with a positive history of lung and other tobacco-related cancers was observed. The finding of an interaction between the variables of familial cancer aggregation and smoking suggests that familial cancer aggregation could be considered as a marker of susceptibility, increasing the risk of lung cancer a mong smokers. These results improve our knowledge of lung carcinogenesis and can guide future cancer genetic studies.

KEY WORDS: Lung cancer. Familial aggregation. Smoking. Case-control study. Interaction.

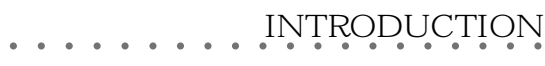

The majority of lung cancer cases, about $90 \%$, can be attributed to cigarette smoking, ${ }^{1}$ but no more than $20 \%$ of smokers develop lung cancer. ${ }^{2}$ The preval ence of tobacco usage is on the increase in developing countries. ${ }^{3}$ 0 ther factors, such as diet, chronic lung diseases, occupational and possibly environmental agents have been shown to contribute to the development of this cancer. ${ }^{4}$ Genetic factors seem to play a role in the causality of lung cancer, but the precise characteristics influencing lung cancer susceptibility are not known. Such genetic factors are easily obscured by the strong environmental determinants of lung cancer, particularly smoking. ${ }^{4}$

Various studies have shown elevations in therisksfor different cancersamong thosewho reported cancer in relatives. ${ }^{5-10}$ Evidence of some degree of familial aggregation of lung cancer is brought out in most familial studies. Since the pioneering study of Tokuhata and Lilienfeld ${ }^{11}$ on familial aggregation of lung cancer, some studies have consistently demonstrated an increased prevalence of cancer among relatives of lung cancer patients, with risks varying from 1.3 to $12.2 .{ }^{12-22}$ H owever, other studies concluded that there was little evidence of familial cancer clusters related to lung cancer risk. ${ }^{23,24}$ Some authors have suggested that a genetic predisposition to lung cancer may contribute to familial aggregation of this cancer. 2,20,22,25 In addition, studies of familial cancer aggregation may provide important insights into the understanding of the interplay between envi- ronmental and genetic risk factors in cancer development.

Lung cancer isthemost common neoplastic disease among Brazilian males and the main cause of death from cancer. Since the 1970s the incidenceand mortality rate of lung cancer have been rising, and during the 1990s have been increasing among females. ${ }^{26}$ This pattern has been associated with an increasein theprevalence of tobacco smoking. ${ }^{27,28} \mathrm{~N}$ o studies have been published on familial cancer aggregation and lung cancer in Brazil. $\mathrm{H}$ owever the results of a case-control study conducted in Rio de Janeiro showed that polymorphism of the Cyp1A1 gene, encoding for an enzyme involved in the metabolism of tobacco carcinogens, was associated with lung cancer risk. ${ }^{29}$

Theobjective of this study was to examine the effect that reported histories of cancer among first-degreerelatives had on lung cancer among the participantsin a case-control study carried out in the metropolitan region of São Paulo (M RSP), an area with high incidence and mortality rates of lung cancer.

...............

A hospital-based case-control study was structured so as to detect incident cases of primary lung cancer among males and females in 14 hospitals where the majority of lung cancer cases in the M RSP are admitted. Information was gathered on cancer in first-degree relatives (parents, siblings and offspring), tobacco smoking, passive smoking in childhood and adult life, socioeconomic status, occupational exposures and medical history. Some additional details on the 
structure of the study and analysis of occupational risk factors have already been described in a previous publication. ${ }^{30}$

A total of 912 persons were included in the analysis, of whom 334 were cases and 578 controls. The cases chosen for the study were newly diagnosed as having lung cancer, according to the International Classification of Disease, ninth revision (ICD-9), ${ }^{31}$ rubric 162, between January 1989 and June 1991. The diagnosis was assessed from hospital records and only cases confirmed by histology or cytology were accepted. C ases confirmed by cytology were assumed to be of undifferentiated histological type. Eligible cases with a definite diagnosis other than lung cancer were reclassified as controls whenever the diagnosis was among those retained as admissible for controls. O nly patients who had been resident for at least six months in the M RSP were included, and all patients were interviewed in person. Controlswereenrolled from the same hospitals and during the same period as the cases, and al so had to have been resident in the M RSP for at least six months. To determine the controls' eligibility, their diagnoses abstracted from medical records were coded according to the ICD-9. Patients with chronic obstructive respiratory diseases, circulatory diseases and smoking-related cancers (bladder, larynx, esophagus, oral cavity, pharynx, pancreas, kidney and renal pelvis) were excluded.

A standard questionnaire specifically drawn up for the gathering of information on the study variables (family cancer history, tobacco smoking, passive smoking, occupation, migration and socioeconomic status) was applied to both casesand controls. Family cancer history was recorded regarding any firstdegree relative (mother, father, sibling, son or daughter) having a cancer at any anatomical site. By means of a structured interview, the health status of each first-degree relative, including the disease diagnosis of sick relatives and the cause of death of deceased relatives were recorded. Pathological confirmation of cancer, and smoking habits of relatives were not obtained.

$O$ dds ratio $(O R)$ and $95 \%$ confidence intervals $(\mathrm{Cl})$ werecal culated as approximations of relative risk. ${ }^{32}$ The risk of lung cancer was estimated by comparing subjects reporting a positivehistory of cancer in first-degreerelatives with thosewho did not. Cases and controls were stratified according to the number of cancer cases in first-degreerelatives and the proportion of reported cases over the total number of relatives. The risk of lung cancer was also estimated for different groups of neoplasm among relatives: lung cancer, tobacco-related cancers other than lung cancer, and other cancers not related to tobacco. The analysis of tobacco smoking was based on categories of cumulative consumption expressed in packyears. The O R and the $95 \% \mathrm{Cl}$ estimates were obtained by non-conditional logistic regression using the maximum likelihood estimate, adjusting for sex, age, smoking and socioeconomic status. Socioeconomic status was classified into four levels based on a combination of income and level of education.

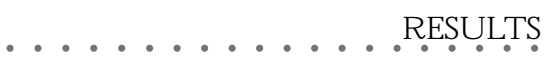

Selected characteristics of casesand controls are shown in Table 1. Of the 334 lung cancer cases $76.6 \%$ were men and among the 578 hospital controls $64.2 \%$ were men. The age range of cases was $36-90$ years, and for controls 33-90 years. In males, squamous cell carcinoma was the most frequent histological type and in females, adenocarcinoma was predominant. O nly 28 lung cancer cases (8.4\%) did not have diagnoses established by histology. The distribution of lung cancer cases according to age, gender and histological type of tumor was similar to what has been reported in previous studies in Brazil ${ }^{33}$ and worldwide. ${ }^{4}$ The main diagnoses for controls were: infectious and parasitic diseases $(23.5 \%)$, non-tobacco related neoplasms $(17.5 \%)$, diseases of the digestive system (15.1\%), endocrine, nutritional, metabolic diseases and immune disorders (7.4\%). The remaining controls had diverse diseases such as bone fracture, rheumatoid arthritis, skin diseases, and in women, childbirth complications. $M$ ales had a higher proportion of infectious diseases and a lower proportion of neoplasms than did females.

From a combination of per capita income and level of education, four socioeconomic tiers were established. $M$ ales in the highest socioeconomic level showed a slightly higher but non-significant risk of developing lung cancer than did those in the lowest tier (OR $1.34 ; 95 \% \mathrm{Cl} 0.79-2.29)$, with this difference being more pronounced among females (OR 3.75; 95\% CI 1.36 - 10.29).

Theprevalence of any cancer in first-degree relatives among cases $(27.2 \%)$ was higher than among controls $(21.3 \%)$, but no statistically significant association was found (OR 1.16; $95 \% \mathrm{Cl} 0.82-1.65)$. N or was any correlation found between the risk of lung cancer and number of cancers among first-degree relatives (Table2). A slight excess risk wasfound within the smokers group (OR 1.24; 95\% Cl 0.81 -

\begin{tabular}{|c|c|c|c|c|}
\hline \multirow[t]{2}{*}{ CHARACTERISTIC } & \multicolumn{2}{|c|}{ MALES } & \multicolumn{2}{|c|}{ FEMALES } \\
\hline & $\begin{array}{c}\text { Cases } \\
(n=207) \\
n(\%)\end{array}$ & $\begin{array}{c}\text { Controls } \\
(n=371) \\
n(\%)\end{array}$ & $\begin{array}{c}\text { Cases } \\
(n=78) \\
n(\%)\end{array}$ & $\begin{array}{c}\text { Controls } \\
\text { (n = 256) } \\
n(\%)\end{array}$ \\
\hline $\begin{array}{l}\text { AGE } \\
<50 \text { years } \\
50-59 \text { years } \\
60-69 \text { years } \\
\geq 70 \text { years }\end{array}$ & $\begin{array}{c}25(9.8) \\
77(30.1) \\
95(37.1) \\
59(23.0)\end{array}$ & $\begin{array}{c}75(20.2) \\
119(32.1) \\
112(30.2) \\
65(17.5)\end{array}$ & $\begin{array}{ll}11 & (14.1) \\
27 & (34.6) \\
29 & (37.2) \\
11 & (14.1)\end{array}$ & $\begin{array}{ll}31 & (15.0) \\
54 & (26.1) \\
82 & (39.6) \\
40 & (19.3)\end{array}$ \\
\hline $\begin{array}{l}\text { HISTOLOGICAL TUMOR TYPE } \\
\text { Squamous cell carcinoma } \\
\text { Adenocarcinoma } \\
\text { Small cell carcinoma } \\
\text { Large cell carcinoma } \\
\text { O ther, mixed and undifferentiated }{ }^{2}\end{array}$ & $\begin{array}{c}120(46.9) \\
59(23.0) \\
36(14.1) \\
11(4.3) \\
30(11.7)\end{array}$ & $\begin{array}{l}- \\
- \\
- \\
- \\
-\end{array}$ & $\begin{aligned} 22 & (28.2) \\
29 & (37.2) \\
12 & (15.4) \\
2 & (2.5) \\
13 & (16.7)\end{aligned}$ & $\begin{array}{l}- \\
- \\
- \\
- \\
-\end{array}$ \\
\hline $\begin{array}{l}\text { DIAGNOSES OF CONTROLS } \\
\text { (ICD-9 } \text { codes }^{3} \text { ) } \\
\text { Infectious and parasitic diseases } \\
(001-139) \\
\text { N on-tobacco related neoplasms } \\
(140-239) \\
\text { Endocrine, nutritional and metabolic } \\
\text { diseases and immune disorders } \\
(240-279) \\
\text { Diseases of the digestive system } \\
(520-579) \\
0 \text { ther diagnoses }\end{array}$ & - & $\begin{array}{l}111(29.9) \\
43(11.6) \\
20(5.4) \\
50(13.5) \\
147(39.6)\end{array}$ & - & $\begin{array}{l}25(12.1) \\
58(28.0) \\
23(11.1) \\
37(17.9) \\
64(30.9)\end{array}$ \\
\hline
\end{tabular}

Age range: 36-90 for cases; 33-90 for controls.

2 Including all tumors confirmed by cytology.

${ }^{3} / \mathrm{CD}-9=$ International Classification of Diseases, $\mathrm{N}$ inth Edition. ${ }^{31}$ 
1.90), and for nonsmokers (OR 1.53; $95 \% \mathrm{Cl}$ $0.61-3.83$ ), among those for whom $10 \%$ or more of their first-degree relatives had a positive history of cancer (Table 3). The risk of lung cancer according to type of cancer, as reported by category of relatives, did not reveal any significant odds ratio (Table 4). As Table 5 demonstrates, there were elevated risks among subjects whose relatives had lung cancer ( $\mathrm{OR}$ $1.73 ; 95 \% \mathrm{Cl} 0.75$ - 3.96) and other tobacco- related cancers (O R 1.67; 95\% CI 1.11 - 2.53). H owever, controlling for smoking dramatically affected the risk for those reporting lung cancer among relatives (OR $1.21 ; 95 \% \mathrm{Cl} 0.50$ 2.92), or other tobacco-related cancers (OR 1.36; $95 \%$ Cl 0.87 - 2.14).

Tobacco smoking was an important risk factor for lung cancer and astep gradient effect was observed in relation to increasing numbers of pack-years of cigarettes smoked, which was

\begin{tabular}{|c|c|c|c|}
\hline Cancer in relatives $^{1}$ & $\begin{array}{c}\text { Cases } \\
(\mathrm{n}=\mathbf{3 3 4})\end{array}$ & $\begin{array}{c}\text { Controls } \\
(n=578)\end{array}$ & $\mathrm{OR}^{2}(95 \% \mathrm{Cl})$ \\
\hline $\mathrm{N}_{\mathrm{one}}{ }^{3}$ & 230 & 429 & 1.0 \\
\hline Any & 91 & 123 & $1.16(0.82-1.65)$ \\
\hline 1 case & 73 & 95 & $1.26(0.86-1.84)$ \\
\hline 2 cases & 15 & 22 & $0.96(0.47-1.99)$ \\
\hline$\geq 3$ cases & 3 & 6 & $0.60(0.13-2.83)$ \\
\hline
\end{tabular}

\begin{tabular}{|c|c|c|c|}
\hline $\begin{array}{l}\text { Percentage of cancer } \\
\text { in relatives }\end{array}$ & $\begin{array}{c}\text { Cases } \\
(n=334)\end{array}$ & $\begin{array}{l}\text { Controls } \\
(\mathrm{n}=578)\end{array}$ & $\mathrm{OR}^{2}(95 \% \mathrm{Cl})$ \\
\hline $\begin{array}{l}\text { TOTAL } \\
<10 \% \\
\geq 10 \%\end{array}$ & $\begin{array}{l}23 \\
65\end{array}$ & $\begin{array}{l}31 \\
87\end{array}$ & $\begin{array}{l}1.15(0.61-2.15) \\
1.12(0.75-1.67)\end{array}$ \\
\hline $\begin{array}{l}\text { SMOKERS }^{3} \\
<10 \% \\
\geq 10 \%\end{array}$ & $\begin{array}{l}22 \\
57\end{array}$ & $\begin{array}{l}19 \\
55\end{array}$ & $\begin{array}{l}1.37(0.71-2.67) \\
1.24(0.81-1.90)\end{array}$ \\
\hline $\begin{array}{l}\text { NONSMOKERS }^{3} \\
<10 \% \\
\geq 10 \%\end{array}$ & $\begin{array}{l}1 \\
8\end{array}$ & $\begin{array}{l}12 \\
32\end{array}$ & $\begin{array}{l}0.44(0.05-3.71) \\
1.53(0.61-3.83)\end{array}$ \\
\hline
\end{tabular}

${ }^{1}$ Any cancer in parents and siblings; ${ }^{2} \mathrm{O} d \mathrm{ds}$ ratio adjusted for gender, age, socioeconomic status (four levels); and smoking (pack-years) for the total group; ${ }^{3}$ Reference category: no cancer reported among relatives.

\begin{tabular}{|c|c|c|c|}
\hline $\begin{array}{l}\text { Cancer in first-degree } \\
\text { relatives }^{1}\end{array}$ & $\begin{array}{c}\text { Cases } \\
(n=334)\end{array}$ & $\begin{array}{l}\text { Controls } \\
(n=578)\end{array}$ & $\mathrm{OR}^{2}(95 \% \mathrm{Cl})$ \\
\hline $\mathrm{N}_{\text {one }}{ }^{3}$ & 230 & 429 & 1.00 \\
\hline $\begin{array}{l}\text { Mother } \\
\text { Any } \\
\text { N ot tobacco-related } \\
\text { Tobacco-related } \\
\text { Lung }\end{array}$ & $\begin{array}{c}27 \\
10 \\
14 \\
3\end{array}$ & $\begin{array}{c}43 \\
19 \\
19 \\
5\end{array}$ & $\begin{array}{l}1.10(0.64-1.91) \\
0.88(0.38-2.04) \\
1.37(0.64-2.94) \\
1.01(0.21-4.97)\end{array}$ \\
\hline $\begin{array}{l}\text { Father } \\
\text { Any } \\
\text { N ot tobacco-related } \\
\text { Tobacco-related }{ }^{4} \\
\text { Lung }\end{array}$ & $\begin{array}{c}28 \\
8 \\
16 \\
4\end{array}$ & $\begin{array}{l}43 \\
17 \\
19 \\
7\end{array}$ & $\begin{array}{l}1.09(0.63-1.89) \\
0.87(0.34-2.19) \\
1.48(0.70-3.13) \\
0.68(0.18-2.53)\end{array}$ \\
\hline $\begin{array}{l}\text { Siblings } \\
\text { Any } \\
\text { N ot tobacco-related } \\
\text { Tobacco-related }{ }^{4} \\
\text { Lung }\end{array}$ & $\begin{array}{c}52 \\
14 \\
31 \\
7\end{array}$ & $\begin{array}{c}61 \\
21 \\
33 \\
7\end{array}$ & $\begin{array}{l}1.20(0.76-1.87) \\
1.10(0.52-2.35) \\
1.29(0.73-2.30) \\
1.05(0.34-3.21)\end{array}$ \\
\hline
\end{tabular}

for lung cancer according to the number of cancer cases stratified into five groups (Table 6). The increase in the risk can be seen from thereports of cancer in relatives for each cumulative consumption pack-years stratum, except for the 1-20 pack-year stratum.

Table 7 shows an analysis of smoking according to two strata of cumulative consumption (0-20 and 21 or more packyears), combined with the dichotomous variable of cancer among relatives. No effect of familial cancer aggregation was detected when there was a consumption of less than 20 pack-years, which suggests an interaction between smoking and familial cancer aggregation. Further stratification by gender or age made no difference to the detection of this interaction (Table 8)

$$
\text { DISCUSSION }
$$

Theobjective of this study wasto examine how familial cancer aggregation affectstherisk of lung cancer. Evidence for the genetic basis of cancer hasincreased over recent decades and thus an assessment of familial cancer aggregation may play an important role in epidemiological studies. Excessive frequency of a trait or disorder within specific families as compared with the population at large is the focus of familial aggregation studies. Various cancer studies havenoted this relationship, but the main problem arising from the results of epidemiological studies lies in the difficulty in balancing the influence of heredity versus shared environmental factors. ${ }^{34}$ Interindividual variation in response to xenobiotics and their potential carcinogenic effects could be mediated by inherited genetic predisposition, although familial aggregation may also be explained by the fact that people of the same family tend to share the same habits, such as tobacco smoking, alcohol drinking, diet and occupation. The ability to disentangle the role of a genetic/familial component from the effect of tobacco smoking on lung cancer risk can improve our knowledge of lung carcinogenesis and have an impact on cancer prevention.

Several studies of familial aggregation of lung cancer have suggested an underlying genetic susceptibility. ${ }^{2,11-13,15-22}$ Sellers et al. ${ }^{14}$ provided strong evidence of $M$ endelian inheritance in lung cancer, but the study by Yang et al. ${ }^{35}$ rejected the $M$ endelian model as an explanation of lung cancer occurrence

Themost recent publications of populationbased studies of familial aggregation of lung cancer used thestrategy of investigating only nonsmokers. 
The study by Schwartz et al. ${ }^{17}$ suggested the hypothesis of genetic susceptibility to lung cancer, since the familial aggregation was found only among the relatives of younger nonsmoking lung cancer casesand among younger relatives. Similar resultswere found by K reuzer et al. ${ }^{19}$ and Yang et al. ${ }^{36}$ Wu et al. ${ }^{16}$ studied only female nonsmokers and found no association between family history of cancer and risk of lung cancer among nonsmokers, but did suggest that the risk of lung cancer increased among females with a female relative (mother or sister) with lung cancer. H owever, thelack of additional information about lifestyle risk factors among the family members restricted theinterpretation of results of that study. Brownson et al. ${ }^{18}$ investigated nonsmokers and ex-smokers and, noting a slight increase in risk, they suggested an interaction between genetic susceptibility and smoking due to the increased chances of lung and oral cavity cancer among former smokers. Yang et al. ${ }^{35}$ studied nonsmoking malesand females, and suggested that the pattern of lung cancer occurrence in families of nonsmoking lung cancer patients differsfrom that in families of smoking lung cancer patients. T hiswas based on the fact that the mean age for the onset of lung cancer among femalerelativeswas 55 years for smokers and 88 years for nonsmokers.

Such results are suggestive of the presence of a high-risk gene contributing to early-onset lung cancer in a population where the probands are nonsmokers. N evertheless, these resultsstill do not clarify whether the evidence supporting a familial association suggests that the etiology of lung cancer includes shared genes or shared environments, or both of these. Certainly, environment factors such as passivesmoking must have some influence on lung cancer occurrence in thefamily. H owever, many other non-environmental mechanisms might provide additional explanations. Such mechanisms may include common genetic polymorphism of carcinogen-metabolizing enzymes, mutations of tumor suppressor genes or variability in D N A repair activity. ${ }^{37}$

The results from this study have revealed a slight, but non-statistically significant, excess lung cancer risk among those who reported tobacco-related cancer cases and lung cancer among first-degree relatives after controlling for the confounding effect of tobacco (Table 5). These results are contrary to those risks found in the classical case-control studies on the influence of familial cancer aggregation factors on lung cancer. ${ }^{11,12} \mathrm{H}$ owever, they are in general compatible with the low excess risk found by Shaw et al., ${ }^{13}$ Wu et al., ${ }^{16}$ Brownson et al. ${ }^{18}$ and $\mathrm{G}$ upta et al. ${ }^{21}$
The magnitude of the risk from familial cancer aggregation was higher among nonsmokers than for smokers, but the odds ratios were not statistically significant (Table 3). H owever, when the influence of smoking on subjects whose relatives had cancer was examined, an interaction was detected (Table 6 and 7).

Kreuzer et al. ${ }^{19}$ detected remarkable differences in lung cancer risk between probands in younger age groups who reported cancer in relatives or not, but not for older age groups. This finding is also supported by the work of Gauderman and Morrison. ${ }^{25}$ In our study there wasno differencein the interaction of cigarette smoking with familial cancer aggregation according to age group ( $<60$ and 60 years and over) or gender (Table 8 ).

The results of this study may have been affected by bias. There may have been interference in family history investigations caused by misclassification. Geographical separation limits the availability of information on family histories of disease, thus resulting in an underreporting of familial cases. $^{38}$ M oreover, positive histories may be inaccurate because metastatic cancer sites can often be mistaken for primary ones. In this

\begin{tabular}{llll} 
& $\begin{array}{c}\text { Table 5. } \mathbf{O} \text { dds ratio for lung cancer according to the } \\
\text { type of cancer in first-degree relatives }\end{array}$ \\
$\begin{array}{l}\text { Type of cancer in } \\
\text { relatives }^{1}\end{array}$ & $\begin{array}{c}\text { Cases } \\
(n=334)\end{array}$ & $\begin{array}{c}\text { Controls } \\
(n=578)\end{array}$ & $O^{2}(95 \% \mathrm{Cl})$ \\
\hline
\end{tabular}

OR adjusted for gender, age and socioeconomic status ${ }^{2}$

$\begin{array}{lccc}\mathrm{N} 0 \text { cancer }^{3} & 239 & 452 & 1.0 \\ \mathrm{~N} \text { ot tobacco-related cancers } & 30 & 54 & 1.02(0.63-1.66) \\ \text { Tobacco-related } & 53 & 60 & 1.67(1.11-2.53) \\ \text { Lung } & 53 & 12 & 1.73(0.75-3.96)\end{array}$

OR adjusted for gender, age, socioeconomic status and smoking ${ }^{5}$ $N$ ot tobacco-related cancers 230 Tobacco-related ${ }^{3}$ 290429 429
53
58
12 1.0 Lung 50
12

${ }_{1}^{1}$ Parents and siblings; ${ }^{2}$ Considering four levels, from level 1 (lowest level) to level 4 (highest level), based on a combination of income per capita and level of education; ${ }^{3}$ Reference category; ${ }^{4}$ Bladder, larynx, esophagus, oral cavity, pharynx, pancreas, kidney and renal pelvis; ${ }^{5}$ Pack-years.

\begin{tabular}{lcccc}
\hline & $\begin{array}{c}\text { Table 6. Joint effect on lung cancer risk of smoking (5 strata) } \\
\text { and cancer among first-degree relatives (2 strata) }\end{array}$ \\
\hline $\begin{array}{l}\text { Smoking } \\
\text { (pack-years) }\end{array}$ & $\begin{array}{c}\text { Any cancer } \\
\text { in relatives }\end{array}$ & $\begin{array}{c}\text { Cases } \\
\text { (n= 334) }\end{array}$ & $\begin{array}{c}\text { Controls } \\
\text { (n = 578) }\end{array}$ & OR $^{2} \mathbf{~ ( 9 5 \% ~ C l ) ~}$ \\
\hline N onsmoker & No & 28 & 162 & 1.00 \\
& Yes & 9 & 47 & $1.08(0.47-2.47)$ \\
$1-20$ & No & 39 & 88 & $3.36(1.87-6.03)$ \\
& Yes & 6 & 24 & $1.86(0.68-5.10)$ \\
$21-40$ & No & 50 & 85 & $5.18(2.80-9.58)$ \\
& Yes & 17 & 19 & $7.17(3.19-16.13)$ \\
$41-60$ & No & 55 & 49 & $8.93(4.78-16.65)$ \\
& Yes & 29 & 18 & $11.73(5.44-25.25)$ \\
$\geq 61$ & No & 58 & 45 & $10.03(5.32-18.91)$ \\
& Yes & 30 & 15 & $14.90(6.68-33.25)$ \\
\hline
\end{tabular}

Parents and siblings; ${ }^{2}$ Adjusted for gender, age and socioeconomic status (four levels).

\begin{tabular}{|c|c|c|c|c|}
\hline $\begin{array}{l}\text { Smoking } \\
\text { (pack-years) }\end{array}$ & $\begin{array}{l}\text { Cancer } \\
\text { in relatives }\end{array}$ & $\begin{array}{c}\text { Cases } \\
(n=334)\end{array}$ & $\begin{array}{l}\text { Controls } \\
(n=578)\end{array}$ & $\mathrm{OR}^{2}(95 \% \mathrm{Cl})$ \\
\hline $0-20$ & $\begin{array}{l}\mathrm{No}^{3} \\
\text { Yes }\end{array}$ & $\begin{array}{l}67 \\
15\end{array}$ & $\begin{array}{c}250 \\
71\end{array}$ & $\begin{array}{l}1.00 \\
0.79(0.42-1.47)\end{array}$ \\
\hline$\geq 21$ & $\begin{array}{l}\text { No } \\
\text { Yes }\end{array}$ & $\begin{array}{c}163 \\
76\end{array}$ & $\begin{array}{c}179 \\
52\end{array}$ & $\begin{array}{l}3.53(2.49-5.01) \\
5.29(3.37-8.30)\end{array}$ \\
\hline
\end{tabular}

${ }^{1}$ Any cancer in parents and siblings; ${ }^{2} 0$ dds ratio adjusted for age and socioeconomic status (four levels); ${ }^{3}$ Reference category. 
study, cancer diagnoses among relatives were not histologically confirmed. Love et al. ${ }^{39}$ estimated the accuracy of family cancer history reports and concluded that information on primary-site cancer among first-degree relatives was $83 \%$ accurate.

The lack of data on relatives' ages may also have distorted the estimates, considering that subjects with older relatives would be expected to have more cancer in the family than would subjects with younger relatives. In an effort to correct for this impediment, we examined the risk by category of firstdegree relative. H owever, no differencein lung cancer risk was noted from reports of cancer occurrences among mothers, fathersor siblings (Table 4).

Another major problem in this study was thelack of dataon smoking among first-degree relatives. Cancer among relatives is likely to be related to smoking exposure within the family and thus, without this information, a familial/genetic effect cannot be clearly separated from the smoking effect. Table 5 shows how the control for smoking exposure affected the $O R$ of the association between cancer among first-degree relatives and lung cancer. This suggests that incorporating information on relatives who smoke might further reduce the observed association.

U se of hospital controls may have caused selection bias, since $11.6 \%$ of male controls and $28.0 \%$ of female controls were cancer patients. If a positive familial history of cancer was a risk factor for cancers at sites other than the lung, then the choice of cancer controls would have resulted in a bias towards nullity. H owever, the exclusion of cancer controls did not modify the results substantially.

Lack of statistical power may have been another potential and additional limitation to this study. Thepredominantly null results presented in Tables 2 to 5 may be due to this fact.

D espite these possible limitations, the findings showing a mild effect of familial aggregation cancers suggest that common susceptibility genes may act to increasetherisk of lung cancer. Reinforcing this, the stratified analysis suggested evidence of an interaction between a positive history of neoplasm in the family and tobacco smoking (Tables 6 and 7). Two facts could possibly explain these interaction findings: (a) residual confounding in the category of 20 and more pack-years; or (b) genetic or environmental familial factors acting on some carcinogenic pathways relevant only for heavy smokers, such as detoxification

\begin{tabular}{|c|c|c|c|c|c|}
\hline & $\begin{array}{c}\text { Smoking } \\
\text { (pack-years) }\end{array}$ & $\begin{array}{c}\text { Cancer } \\
\text { in relatives }\end{array}$ & $\begin{array}{c}\text { Cases } \\
(n=334)\end{array}$ & $\begin{array}{l}\text { Controls } \\
(n=578)\end{array}$ & OR $^{2}(95 \% \mathrm{Cl})$ \\
\hline \multicolumn{6}{|l|}{ GENDER } \\
\hline $\begin{array}{l}\text { Males } \\
\text { Females }\end{array}$ & $\begin{array}{l}0-20 \\
\geq 21 \\
0-20 \\
\geq 21\end{array}$ & $\begin{array}{l}\mathrm{No}^{3} \\
\text { Yes } \\
\mathrm{No} \\
\text { Yes } \\
\mathrm{No}^{3} \\
\text { Yes } \\
\mathrm{No} \\
\text { Yes }\end{array}$ & $\begin{array}{c}29 \\
4 \\
148 \\
66 \\
38 \\
11 \\
15 \\
10\end{array}$ & $\begin{array}{c}120 \\
29 \\
163 \\
45 \\
130 \\
42 \\
16 \\
7\end{array}$ & $\begin{array}{l}1.00 \\
0.50(0.16-1.56) \\
3.84(2.39-6.16) \\
5.50(3.13-9.68) \\
1.00 \\
0.93(0.43-2.04) \\
3.25(1.42-7.42) \\
4.89(1.68-14.25)\end{array}$ \\
\hline $\begin{array}{l}\text { AGE } \\
<60 \text { years }\end{array}$ & $\begin{array}{l}0-20 \\
\geq 21 \\
0-20 \\
\geq 21\end{array}$ & $\begin{array}{l}\mathrm{No}^{3} \\
\text { Yes } \\
\mathrm{No} \\
\text { Yes } \\
\mathrm{No}^{3} \\
\text { Yes } \\
\mathrm{No} \\
\text { Yes }\end{array}$ & $\begin{array}{c}30 \\
7 \\
72 \\
27 \\
37 \\
8 \\
91 \\
49\end{array}$ & $\begin{array}{l}122 \\
27 \\
100 \\
24 \\
128 \\
44 \\
79 \\
28\end{array}$ & $\begin{array}{l}1.00 \\
1.00(0.39-2.56) \\
3.66(2.07-6.46) \\
4.96(2.45-10.07) \\
1.00 \\
0.62(0.27-1.45) \\
3.86(2.25-6.63) \\
5.74(2.97-11.09)\end{array}$ \\
\hline
\end{tabular}

${ }^{1}$ Parents and siblings; ${ }^{2} 0$ dds ratio adjusted for age, gender and socioeconomic status (four levels); ${ }^{3}$ Reference category. or damage repair above a certain threshold.

Tobacco smoking, the main environmental risk factor for lung cancer, is strictly dependent on cultural and demographic characteristics. Recent studieshave suggested that theinitiation of smoking and nicotine dependence may belinked to genetic factors. ${ }^{40} \mathrm{~T}$ here is considerable variation in individuals' susceptibility to lung cancer, and it has been postulated that this is due to genetic polymorphisms of carcinogen metabolizing enzymes. ${ }^{41} \mathrm{H}$ owever, no clear mechanisms have been established to explain this relationship of interactions between genetic polymorphisms and tobacco carcinogen metabolism, and their further effects on lung cancer. For example, glutathioneS-transferase (GST ) null genotypes seem to be related to a higher incidence of polycyclic aromatic hydrocarbon D N A adducts and a higher risk of lung cancer, ${ }^{42-45}$ yet somestudies havefound no such associations. ${ }^{46} \mathrm{O}$ ne study showed an increased risk of lung cancer among individual scombining GST null genotype and a smoking consumption of at least 35 packyears. ${ }^{47}$ Certainly, many tobacco carcinogens are metabolized by enzymes of the P450 cytochrome family and GST family. Polymorphisms of cytochromeP450, Cyp1A1 and Cyp1A2, and the GST isoenzyme GSTM 1 could have implications for polycyclic aromatic hydrocarbon metabolism..$^{48} \mathrm{~T}$ hismay explain theincreasesin the probability of lung cancer among smokers of morethan 20 packyears, as found in this study.

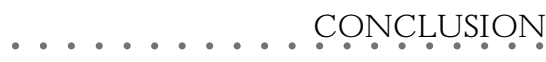

Thisstudy reports resultsfrom a hospitalbased case-control study showing a mildly elevated risk of lung cancer among persons with a positivefamily history of lung and other tobacco-related cancers. The results suggest that familial cancer clusters may have some connections with tobacco smoking. The finding of an interaction between the variables of familial cancer aggregation and cigarette smoking on the risk of lung cancer may guide future genetic studies and improve our knowledge of lung cancer carcinogenesis. 
1. Parkin D M, Pisani P, Lopez AD, M asuyer E. At least one in seven cases of cancer is caused by smoking: global estimates for 1985. Int J Cancer 1994;59:494-504.

2. Wood M E, Kelly K, M ullineaux LG, Bunn PA Jr. Theinherited nature of lung cancer: a pilot study. Lung $C$ ancer 2000;30:13544.

3. World H ealth O rganization. The tobacco epidemic: a global public health emergency. Tobacco Alert, A pril 1996. Available on website: [www.who.int/archives/tobalert/apr96/ fulltext.html].

4. Blot WJ, Fraumeni JF Jr. Cancers of lung and pleura. In: Schottenfeld D , Fraumeni JF Jr., editors. C ancer epidemiology and prevention. $2^{\text {nd }}$ ed. N ew York: 0 xford University Press; 1996.p.637-65.

5. Goldgar DE, Easton DF, Cannon-Albright LA, Skolnick MH . Systematic population-based assessment of cancer risk in firstdegree relatives of cancer probands. J $\mathrm{N}$ atl $\mathrm{C}$ ancer Inst 1994;86:1600-7

6. Foulkes WD, Brunet JS, Kowalski LP, N arod AS, Franco EL. Family history of cancer is a risk factor for squamous cell carcinoma of the head and neck in Brazil: a case-control study. Int J Cancer 1995;63:769-73.

7. OIsen JH, Boice JD Jr, Seersholm N, Bautz A, Fraumeni JF Jr. Cancer in the parents of children with cancer. N Engl J M ed 1995;333:1594-9.

8. Anderson $\mathrm{KE}, \mathrm{W} 00 \mathrm{C}, \mathrm{O}$ Ison $\mathrm{JH}$, et al. Association of family history of cervical, ovarian, and uterine cancer with histological categories of lung cancer: the lowa Women's H ealth Study. Cancer Epidemiol Biomarkers Prev 1997;6:401-5.

9. Hemminki K, Vaittinen P. N ational database of familial cancer in Sweden. Genet Epidemiol 1998;15:225-36.

10. Zhu K, Levine RS, Gu Y, et al. N on-H odgkin's lymphoma and family history of malignant tumors in a case-control study (United States). Cancer Causes Control 1998;9:77-82.

11. Tokuhata GK, Lilienfeld AM . Familial aggregation of lung cancer in humans. J N atl Cancer Inst 1963;30:289-312.

12. Oii WL, Elston RC, Chen VW, Bailey-Wilson JE, Rothschild $\mathrm{H}$. Increased familial risk for lung cancer. J $\mathrm{N}$ atl $\mathrm{C}$ ancer Inst 1986;76:217-22.

13. Shaw GL, Falk R, PickleLW, M ason T J, Buffler PA. Lung cancer risk associated with cancer in relatives. J Clin Epidemiol 1991;44:429-37.

14. SellersTA, Elston RC, Atwood LD, Rothschild H . Lung cancer histologic type and family history of cancer. Cancer 1992;79:86-91.

15. AmbrosoneCB, Rao U, M ichalek AM , CummingsKM, M ettlin CJ. Lung cancer histologic types and family history of cancer. Analysis of histologic subtypes of 872 patients with primary lung cancer. Cancer 1993;72:1192-8.

16. Wu AH, Fontham ET, Reynolds P, et al. Family history of cancer and risk of lung cancer among lifetime nonsmoking women in the United States. Am J Epidemiol 1996;143:535-42.

17. SchwartzAG, Yang P, Swanson GM . Familial risk of lung cancer among nonsmokers and their relatives. Am J Epidemiol
1996;144:554-62.

18. Brownson RC, Alavanja MC, Caporaso N, Berger E, Chang IC. Family history of cancer and risk of lung cancer in lifetime non-smokers and long-term ex-smokers. Int J Epidemiol 1997;26:256-63

19. Kreuzer $M$, Kreienbrock $L$, Gerken $M$, et al. Risk factors for lung cancer in young adults. Am J Epidemiol 1998;147:102837

20. Schwartz AG, Rothrock M, Yang P, Swanson GM . Increased cancer risk among relatives of nonsmoking lung cancer cases Genet Epidemiol 1999;17:1-15.

21. Gupta D, Aggarwal AN, Vikrant S, Jindal SK. Familial aggregation of cancer in patients with bronchogenic carcinoma. Indian J Cancer 2000;37:43-49.

22. Bromen K, Pohlabeln H, Jahn I, Ahrens W, Jockel KH Aggregation of lung cancer in families: resultsfrom a populationbased case-control study in Germany. Am J Epidemiol 2000;152:497-505

23. Li H, Yang P, Schwartz AG. Analysis of age of onset data from case-control family studies. Biometrics 1998;54:1030-9.

24. TomizawaY, Adachi J, Kohno T, Yamaguchi N , Saito R, Yokota $J$. Identification and characterization of families with aggregation of lung cancer. Jpn J Clin O ncol 1998;28:192-5.

25. Gauderman WJ, M orrison JL. Evidence for age-specific genetic relative risks in lung cancer. Am J Epidemiol 2000;151:41-9.

26. M inistério da Saúde [M inistry of $\mathrm{H}$ ealth]. Fundação $\mathrm{N}$ acional de Saúde[ $\mathrm{N}$ ational $\mathrm{H}$ ealth Foundation]. Sistemadel nformações sobre M ortalidade[M ortality information system]. D ados deD eclaração de Ó bito 1979-1996 [D ata from D eath Certificate 1979-1996]. Braślia, DF: Centro de D ocumentação do M inistério da Saúde [M inistry of $\mathrm{H}$ ealth D ocumentation Center]; 1997.

27. Coleman M P, Esteve J, D amiecki P, Arslan A, Renard H . Trends in cancer incidence and mortality. Lyon: IARC Press; 1993. (IARC Scientific Publications N. 121)

28. Fonseca LAM . A evolução das doenças neoplásicas [Evolution of neoplastic diseases]. In: M onteiro CA, editor. Velhos enovos males da saúde no Brasil: a evolução do país e de suas doenças [ $\mathrm{N}$ ew and old health problems in Brazil: the evolution of the country and its diseases]. São Paulo: H ucitec; 1995.p.268-78.

29. H amada GS, Sugimura H, Suzuki I, et al. The hemebinding region polymorphism of cytochromeP450IA1 (Cyp1A1), rather than the Rsal polymorphism of IIE1 (CyplIE1), is associated with lung cancer in Rio de Janeiro. Cancer Epidemiol Biomarkers Prev 1995;4:63-7.

30. W ünsch-Filho $V$, M oncau JEC, M irabelli $D, B$ offetta $P$. O ccupational risk factors of lung cancer in São Paulo, Brazil. Scand J Work Environ Health 1998;24:118-24.

31. World $\mathrm{H}$ ealth $\mathrm{O}$ rganization. International Classification of Diseases. M anual of the International Statistical Classification of D iseases, Injury and C auses of D eath. N inth Revision, 1975. Geneva: World $\mathrm{H}$ ealth O rganization; 1975.

32. Breslow NE, D ay NE. Statistical methods in cancer research. Vol. 1: The analysis of case control studies. Lyon: IARC Press; 1980. (IARC Scientific Publications N. 32)
33. Suzuki L, H amada G S, Zamboni M M , Cordeiro PB, Watanabe S, Tsugane S. Risk factors for lung cancer in Rio de Janeiro, Brazil: a case-control study. Lung Cancer 1994;11:179-90.

34. Susser M. Separating heredity and environment. Am J Prev M ed 1985;1:5-23

35. Yang $P$, Schwartz AG, M CAllister AE, Aston CE, Swanson GM $G$ enetic analysis of families with nonsmoking lung cancer probands. Genet Epidemiol 1997;14:181-97.

36. Yang P, Schwartz AG, M CAllister AE, Swanson G M , Aston CE Lung cancer risk in families of nonsmoking probands: heterogeneity by age at diagnosis. Genet Epidemiol 1999;17:253-73

37. Vineis $P, M$ alats $N$, Boffetta P. Why study metabolic susceptibility to cancer? In: VineisP, M alats N , Lang M , d'Errico A, C aporaso N , C uzick J, Boffetta P. M etabolic polymorphisms and susceptibility to cancer. Lyon: IARC Press; 1999.p.1-3. (IARC Scientific Publications N. 148).

38. Skeel RT, Schiefeling D J, H orton J, Talefski TJ. Practical guide to cancer genetics, origin and prevention. Disease-a-month 1997;43:692-715

39. LoveRD, EvansAM, Josten D M . Theaccuracy of patient reports of a family history of cancer. J Chrn D is 1985;38:289-93.

40. Bergen AW, C aporaso N . Cigarette smoking. J N atl C ancer Inst 1999;91:1365-75

41. Raunio $\mathrm{H}, \mathrm{H}$ usgafvel-Pursiainen $\mathrm{K}$, Anttila $\mathrm{S}, \mathrm{H}$ ietanen $\mathrm{E}$, $\mathrm{H}$ irnoven $\mathrm{A}$, Pelkonen $\mathrm{O}$. Diagnosis of polymorphisms in carcinogen-activating and inactivating enzymes and cancer susceptibility - a review. Gene 1995;159:113-21.

42. N azar-Stewart V, M otulsky AG , Eaton D L, et al. T heglutathione S-transferase mu polymorphism as a marker for susceptibility to lung carcinoma. Cancer Res 1993;53(Suppl 10):2313-8.

43. $N$ akagima $T$, Elovaara $E$, Anttila $S$, et al. Expression and polymorphism of glutathioneS-tran fferase in human lungs: risk factors in smoking-related lung cancer. Carcinogenesis 1995;16:707-11.

44. Bartsch H, Rojas M, Nair U, N air J, Alexandrov K. Genetic cancer susceptibility and DNA adducts: studies in smokers, tobacco chewers, and cokeoven workers. Cancer D etect Prev 1999;23:445-53.

45. Butkiewicz D, Grzybowska E, Phillips DH, H emminki K, Chorazy M . Polymorphisms of the GST P1 and GST M 1 genes and PAH -DNA adducts in human mononuclear white blood cells. Environ M ol M utagen 2000;35:99-105.

46. Heckbert SR, Weiss NS, H ornung SK, Eaton DL, M otulsk AG. Glutathione S-transferase and epoxide hydrolase activity in human leukocytes in relation to risk of lung cancer and other smoking-related cancers. J N atl Cancer Inst 1992;84:414-22.

47. Jourenkova-M ironova $\mathrm{N}$, Wikman $\mathrm{H}$, Bouchardy C, et al. Role of glutathione S-transferase GST M 1, GST M 3, GST P1 and GSTT 1 genotypes in modulating susceptibility to smokingrelated lung cancer. Pharmacogenetics 1998;8:495-502.

48. W ünsch-Filho V, G attás GJF. Biomarcadores moleculares em câncer: implicações para a pesquisa epidemiológica e a saúde pública. Cad Saúde Pública 2001;17:467-80. 
.. Publ ish ing infor mat io n.

Acknowledgements: We acknowledge with thanks the contribution of the medical staffs from hospitals where the study was conducted, particularly: Antonio Pedro Mirra, AC Camargo Hospital; José R. Pereira, AV de Carvalho Institute; João V. Barbas Filho and Tereza Takagaki, University of São Paulo C linical Hospital; Hakaru Tadakaru and Sérgio Jamnik, São Paulo Hospital/ Federal University of São Paulo Hospital; Salvador Mercúrio, Heliópolis Hospital; Jorge A fiune, Clemente Ferreira Institute; $\mathrm{N}$ elson Morrone, Luiz AM Fonseca and Carlos AC Pereira, Ipiranga Hospital; Ilka Santoro, Mandaqui Hospital; Mozart T de Lima, State Workers' Hospital; Jorge N akateni, Santa M arcelina Hospital; Roberto Saad Jr. and Jorge Ethel Filho, Santa Casa São Paulo Hospital.

Victor Wünsch-Filho, MD, PhD. Department of Epidemiology, Public Health School, University of São Paulo, São Paulo, Brazil.

Paolo Boffetta, MD. Unit of Environmental Cancer Epidemiology, International Agency for Research on Cancer, World Health 0 rganization, Lyon, France.

Didier Colin, BSc. Unit of Environmental Cance Epidemiology, International A gency for Research on C ancer, World Health 0 rganization, Lyon, France.

José Eduardo Moncau, MD, PhD. Department of Preventive M edicine, Federal University of São Paulo, São Paulo, Brazil.

Sources of funding: This research was supported by funds from the São Paulo Metropolitan Health Program/ World Bank.

Conflict of interest: $\mathrm{N}$ one

Date of first submission: 23 September 2001

Last received: 50 ctober 2001

Accepted: 310 ctober 2001

\section{Address for correspondence:}

Victor W ünsch-Filho

Departamento de Epidemiologia, Faculdade de

Saúde Pública, Universidade de São Paulo.

Av. Dr. Arnaldo, 715

São Paulo/ SP - Brasil - CEP 01246-904

Tel. (+55 11) 3066-7764

E-mail: wunsch@usp.br
INT RODUÇ̃̃o: Cerca de $90 \%$ dos casos de câncer de pulmão no mundo são atribuíveis ao tabagismo, porém menos de $20 \%$ dos fumantes desenvolvem câncer de pulmão. Fatores como dieta, doenças pulmonares crônicas, ocupação e, possivelmente, exposições ambientais também têm papel na etiologia desse câncer. $0 \mathrm{~s}$ fatores genéticos parecem influir na ocorrência da doença, mas as características que influenciam a suscetibilidadeàneoplasia pulmonar não são precisamente conhecidas, obscurecidas pela forte influência dos fatores ambientais na determinação da doença, particularmente o tabagismo.

OBJETIVOS: Estimar o efeito da ocorrência de câncer em parentes de primeiro grau no risco de câncer de pulmão.

TIPO DE EST UD O: Estudo caso-controle de base hospitalar.

LOCAL: Região M etropolitana de São Paulo.

PART ICIPANTES: 334 casos de neoplasia pulmonar e 578 controles emparelhados por hospital.

VARIÁVEIS EST UDAD AS: Casos e controles foram entrevistados com respeito ao passado de neoplasias em parentes de primeiro grau, tabagismo, tabagismo passivo, ocupação, migração e status socioeconômico. Utilizouse a regressão logística não-condicional para calcular o risco de câncer em familiares, 0 efeito conjunto de câncer em familiares e uso detabaco, epara controlar potenciais variáveis
RESUMO

de confusão.

RESULTAD O S: 0 odds ratio (OR) ajustado revelou um discreto excesso de risco para câncer de pulmão, não estatisticamente significante, entre osindivíduos com história de câncer de pulmão na família (OR 1,21; intervalo deconfiança de $95 \%$ [IC 95\%] 0,50 - 2,92) ou entre aqueles com história de outros cânceres relacionados ao tabaco na família (OR 1,36; IC 95\% 0,87-2,14). Foi observado um efeito dose-resposta positivo para o risco de câncer de pulmão de acordo com o aumento do consumo de cigarros. D etectou-se uma interação entre as variáveis câncer na família e tabagismo.

CON CLU SÕ ES: O bservou-se um discreto aumento do risco de câncer de pulmão entre indivíduos com história positiva na família de câncer de pulmão e outros cânceres relacionados ao tabaco. Esses resultados sugerem que a presença de aglomerados de câncer na família pode ser considerada como um marcador de suscetibilidade e aumenta 0 risco de câncer de pulmão entre os fumantes. A interação detectada entre as variáveis agregadas de câncer na família e tabagismo no risco de câncer de pulmão éuma contribuição no conhecimento dos mecanismos da carcinogênese e poderá orientar futuras pesquisas no campo da genética do câncer.

PALAVRAS-CH AVE: Câncer pulmão. Câncer na família. Tabagismo. Estudos caso-controle. Interação. 